\title{
THE BLACK ECONOMY IN TURKEY: AN EMPIRICAL INVESTIGATION
}

\author{
Dr. Ferda HALICIOGLU*
}

\section{INTRODUCTION}

One important result of the financial liberalization attempts in the $1980 \mathrm{~s}$ and in the 1990s is the widespread belief that there is a considerable number of black economic activities taking place in the Turkish economy.

A number of media have highlighted cases of tax evasion, money laundring businesses, drug traffickings, smuggling, different forms of financial frauds aiming at public funds and of spectacular sums carned through various illegal activities.

Even in daily transactions, there is some degree of concealed figures existing between buyers and sellers which is also attributed in part to the black economy.

As a consequences of the above-mentioned situations, it is believed that the size of the black economy has been increasing rapidly. Moreover, several studies have been carried out to determine the size of the black economy and have produced different results which are, of course, consistent with their methodology.

The aim of this paper is to present fresh evidence on the scale of the black economy in Turkey. Nevertheless, it should be noted that the results of this paper should be treated with certain limitations as the measurement method adopted here is an indirect means of the size of the black economic activities. As a nature of the hidden activities, there is no single method to capture the extent of these activities.

Thus, this paper is formed as follows: Section 2 presents some major definitional issues on the black economy and causes and consequence of it. Section 3 briefly reviews the main measurement methods of the black economy with references to the relevant empirical studies in the Turkish context. Section 4 introduces the estimation methodology that this paper adopted. Section 5 presents the results of the estimation

\footnotetext{
* Assistant Professor of Economics, Istanbul University, Faculty of Economics, Department of Economics.
} 
with the relevant evaluations. Section 6 draws some conclusions on the estimated size of the black economy in Turkey.

\section{DEFINITIONS, CAUSES AND CONSEQUENCES OF BLACK ECONOMY}

\subsection{Some Definitions of Black Economy}

Early studies in the black sconomy in the 1980s note that several conceptional divisions have been put forward to describe the total economic activities in an economy. Existing literature on the black economy distinquishes the divisions of the total economy activities in several forms such as official-unhofficial, formal-informal, registeredunregistered, observed-unobserved, formal-shadow, formal-underground, formalsubterranean, official-parallel, unhiclden-hidden, regular-irregular, ctc.

Although there is little disagreement over the definition of the first component of the total economic activities, there is considerable disagreement over the latter component of the total economic activities. As a result, there is not a widely accepted definition for the latter component of the lotal economic activitics in an economy.

According to the laading economist, Vito Tanzi (1980), who has done the pionecring study in this field, "Underground economy is gross national product that because of unreporting and/or underreporting is not measured by official statistics" (Tanzi, 1980:428).

Whereas, Frey et al. (1982) defines the latter component of the total economic activities an "economic activities thal contribute to value added and which should be included in national income according to national accounting conventions, but which is presently not registered by the societal measurement agent" (Frey et al. 1982:409).

This paper however adopts a very convenient and simple definition of the latter component of the total econcmic activities the one put forward by Smith (1986) and also adopted by Fagan (1997) and which is illustrated in Chart 1.

According to Smith (1986), "Total economic activities comprise all production of goods and services whether sold in markets or not. The formal economy is that portion of total economic activity which appears in official estimates of national income. It includes both recorded market activity and non-market activity such as public administration and various imputations (e.g. If nt on owner-occupied housing)" (Smith (1986), cited in Fagan 1997:20). 


\section{Chart 1: The Shadow Economy, The Formal Economy and The Black Economy}

FORMAL ECONOMY

\begin{tabular}{|c|c|c|c|c|c|c|}
\hline \multicolumn{2}{|c|}{$\begin{array}{l}\text { NON-MARKET } \\
\text { ECONOMY }\end{array}$} & \multirow{2}{*}{$\begin{array}{c}\text { MARKET } \\
\text { ACTIVITY } \\
\begin{array}{c}\text { GOODS AND } \\
\text { SERVICES } \\
\text { INCLUDED IN } \\
\text { OFFICIAL GDP }\end{array}\end{array}$} & \multicolumn{2}{|c|}{$\begin{array}{l}\text { BLACK } \\
\text { ECONOMY }\end{array}$} & \multicolumn{2}{|c|}{$\begin{array}{c}\text { NON-MARKET } \\
\text { SHADOV } \\
\text { ECONOMY }\end{array}$} \\
\hline $\begin{array}{c}\text { IMPUTED } \\
\text { ITEMS }\end{array}$ & $\begin{array}{l}\text { GOVERNMENT } \\
\text { SPENDING }\end{array}$ & & $\begin{array}{c}\text { TAX } \\
\text { EVASION }\end{array}$ & $\begin{array}{l}\text { CRIME } \\
\text { PRODUCTION } \\
?\end{array}$ & $\begin{array}{l}\text { HOUSEHOLD } \\
\text { ECONOMY }\end{array}$ & $\begin{array}{l}\text { VOLUNTARY } \\
\text { WORK }\end{array}$ \\
\hline \multicolumn{3}{|c|}{$\begin{array}{c}\text { MEASURED GROSS DÓMESTIC } \\
\text { PRODUCT }\end{array}$} & \multicolumn{2}{|r|}{ A } & \multicolumn{2}{|c|}{ B } \\
\hline
\end{tabular}

A- Activitics that should, in principle, be included in measured GDP, but are not because they are hidden.

B- Activities excluded from GDP by convention Source: Fagan (1997) p. 20.

Accord to Smith (1986), the shadow economy comprises that part of the total economic activity which is excluded from the official measurement process. Some items are excluded for conceptual reasons (e.g. home production, Do It Yourself (DIY) and gardening). However, other components are not recorded because of the desire of participants to conceal their activities (e.g. crime or tax evasion). This component of the shadow economy is defined by Smith (1986) as the black economy (Smith, 1986, cited in Fagan, 1997: 20-21). This paper also focus on the type of black economy that Smith (1986) described. Smith (1986) also defines the black economic activities in a broader framework, that these activities include various components of individual or corporate incomes which are not reported to the authorities in order to evade taxation. For example, working while claiming unemployment benefits, prostitution, selling illegal drugs and different types of financial frauds. In Fagan (1977), these black economic activities are presented in a systematic order which is also adopted in this paper and presented in Chart 2. 
Chart 2: Typical Activities in the Black Economy

\begin{tabular}{|c|c|}
\hline \multicolumn{2}{|c|}{ BLACK ECONOMY } \\
\hline HOUSEHOLD AN INDIVIIJUALS & \multirow{2}{*}{$\begin{array}{l}\text { PRIVATE COMPANIES } \\
\text { Off the books business (sales } \\
\text { that are unrecorded to reduce } \\
\text { sales and profits liability tax) }\end{array}$} \\
\hline $\begin{array}{l}\text { Incomes not declared for tax. } \\
\text { (e.g. income from sezond } \\
\text { jobs, moonlighting, tips and } \\
\text { gratuities under-reported self- } \\
\text { employment income stc.) }\end{array}$ & \\
\hline Undeclared incomes in kind & $\begin{array}{l}\text { False accounting for PAYE or } \\
\text { National Insurance deductions }\end{array}$ \\
\hline Working and claiming & $\begin{array}{l}\text { Private expenditures (cars, en- } \\
\text { tertainment) put down as com- } \\
\text { pany costs }\end{array}$ \\
\hline $\begin{array}{l}\text { Production of illegal goods } \\
\text { and services (e.g. drugs, pros- } \\
\text { titution) }\end{array}$ & Inter company barter \\
\hline
\end{tabular}

Souce: Fagan (1997) p. 21.

\subsection{Causes and Consequences of the Black Economy}

There is a vast verbal literature on the possible determinants and consequences of the shadow economy. Obviously, as a sub-group of the shadow economy, the black economic activities are determined by almost the same determinants and have almost the same implications.

In general, there are two major causes distinguished, as put forward by Gutmann (1977) and Tanzi (1980):

i) Taxes

ii) Regulations

Gutmann (1977) argues that the government and its rules is the major rason for the existence of subterranean exonomy. According to Tanzi (1980), both of these factors can bring about an underground economy. Tanzi (1980) argues moreover that all kind of taxes cause some degree of underground activities. But in a given country at a given time, certain taxes are likely to be more important than others (e.g. in the USA, income taxes; in Eurore, social security taxes and VATs; and in the case of developing countries, 
foreign trade taxes). Tanzi (1980) also argues that if there were no taxes, there would still be underground economy because of various governmental restrictions on the activities of economic agents. The restrictions are imposed either because of inherently criminal or illegal reasons or for socioeconomic reasons. As these activities still use resources and generate incomes, they inevitably bring into existence the underground economy.

Even some restrictions on legal activities cause the underground economy to some degree, in the form of underpayment of taxes or wclfare payments, paying wages below the legal minimum, etc. (Tanzi, 1980:428-229).

Frey et al. (1983) argue that factors such as "tax morality", the vote of unemployment and the level development of an economy also be included as the consequences of the shadow economy. They argue that an individual feels that the government spends the taxes inadequately or as the unemployment level increases or economic developmentlevel is low, then there will be incentive for the individuals to participate in the shadow economy (Frey et al., 1984:37-39).

Tanzi (1980) argues that the existence of a substantial underground economy would have important and, at times, disturbing implications for the measurement of macroeconomic variables, the pursuit of economic policy and the efficient functioning of the economy. For example, employment statistics may overestimate unemployment rates as a result of the underground economy (Tanzi, 1980:450-451).

The same points, to some extent, are also put forward by Gutmann (1977) (Gutmann, 1977:26-27). Tanzi (1980) also argued that the prices were likely to be lower in the shadow economy because of lower costs due to not paying taxes or not buying licences to operate businesses; therefore the growth of the actual economy would be higher than the measured growth. Of course, as a result of these biased measurements in the crucial macroeconomic variables, the efficiency of monetary and fiscal policies will be adverscly affected (Tanzi, 1980:451-452).

\section{MEASUREMENT METHODS FOR THE BLACK ECONOMY}

It is quite a contradiction in itself that we try to measure something which is either hidden or not registered. Indeed, the main aim of the participarts of the black economy is to hide or nol register their activitics so that they can evade taxes or prosecution. As a consequence of these complex activities, the estimation of the scale of the black economy presents a very difficult issue in the applied economics. However, over the years, a number of quantitative and non-quantative measurement techniques have been developed to trace the magnitude of the black economy in an economy.

Frey et al (1984) distinguish basically four approaches for measuring the size of the black economy compared to a formal economy (Frey et al. 1984:34-35).

i) Tax Evasion Approach: This method employs several tax auditing techniques in order to uncover hidden income. But this method has got a major shortcoming since the selection of tax payers for tax audit is not random. And the estimates reflect only a proportion of the black economy being disclosed. This approach has been applied in the Turkish context by Derdiyok (1993) and Temel et al (1994) and pointed that the size of black economy to the formal 
economy is 40 and 30 percent respectively (L)erdiyok 1993:60 and Temel et al 1994:32).

ii) National Accounts Approach: This method u:es different estimates of national income. The initial discrepencies between income and expenditure based national accounts can be attributed to the hidden economy. This approach has been used in the 'Turkish context by Ozsojlu (1993) and estimated that in 1990, total expentidure exceeded total income by 7.5 percent (Özsoylu, 1993:46).

iii) Employment Approach: 'This approach uses the official employment level and the participation rate 10 the official emplisyment level. A decline in the participation rate to official employment levil is considered to be an increase in the scalc of the black economy.

iv) Monctary Approach: This approach is the most popular of all the approaches. There are basically three different techniques being used to identify the size of the black economy through monetary variables. The first monetary method is the constant rate approach. According to this approach, the velocity of money is assumed to be constant, if the velocity money increases, it indicates an increase in the siza of the black economy. In this context, the size of black economy in Turkey, has been estimated by Özsoylu (1993) and Temel et al (1994) and respective figures were 11.7 percent and 1.91 percent (Özsoylu, 1993:349 and Temel et al. 1993:32).

The second monctary method is the transaction approach. This method uses the quantity equation and deduces from the total quantity of money is what the size of total economic activity has to be. Substracting official GNP from the therebly estimated total GNP gives an estimate of the GNP of the hidden sector Özsoylu (1993) and Temel et al (1994) also estimated the size of the black economy by using the transaction approach for the Turkish context and reported the following respective results of 11.7 percent and 1.91 percent (Özsoylu, 1993:50 and Temel et al. 1994:32).

The last monetary method is an econometric application of this approach. With this method, the demand for unoney or cash holdings is estimated econometrically twice, one with a relevant tax variable, one without it. The diffarence between the estimations is attributed to the size of black sconomy.

According to this approach, the size of the black sconomy will increase as the rate of tax burden increases. It is also assumed that the velority of money is the same both in the formal and informal economy. This approach has also been applied by Kasnakoglu (1993) and Temel et al (199.4) to determine the size of the black economy in Turkey. They pointed out that the size of the black economy relative to the formal economy was 9.6-22.6 and 7.88 percent respectively (Kasnakoğlu, 1993:101 and Temel et al., 1994:32).

Monetary approaches have some major flaws but the most important one is that the demand for currency reflects a number of factors other than the extent of the black economy. 


\section{ESTIMATION METHODOLOGY}

By and large, all monetary approaches use the standard quantity theory of money to measure the size of the black economy. According to the standard quantity theory of money:

\section{M. $\mathrm{V}=\mathrm{Y}$}

where $\mathrm{M}$ is the total money stock (supply), $\mathrm{V}$ is the velocity of money, and $\mathrm{Y}$ is the total nominal income. Moreover, it is also assumed that the velocity of money is in the black economy and the formal economy is equal to each other namely:

$$
\mathrm{V}_{\mathrm{O}}=\mathrm{V}_{\mathrm{B}}=\mathrm{V}
$$

where $V_{O}$ is the velocity of money in the formal economy, and $V_{B}$ is the velocity of money in the black economy.

Providing that the amount of the money holdings in the black economy is available, we can finhd the total income generated in the black economy by using the following equation:

$Y_{B}=M_{B} \cdot V_{B}$

where $Y_{B}$ is the amount of income generated in the black economy and $M_{B}$ is the estimated amount of the money holdings in the black economy. On estimating $M B$, the approach of Cagan (1958) is extensively used. According to Cagan (1958), one of the detcrminants of the demand for currency relative to the total money stock is tax burden which is also considered to be the main driving force behind the black economy (Cagan, 1958: 319-320). Hence the participants of the black economy prefer to hold money in the forms of currency in order to avoid taxation and prosecution. As a result, the currency, holdings are the key proxy variablyc in the monetary approaches to determine the size of the black economy. In the existing literature of the demand for currency, there are several variables such as income, interest rates, inflation, exchange rates, etc in determining the demand for currency. Adding the tax burden variable to these variables, we can write the function of currency holdings and expected relations between dependent and independent variables as follow:

$$
\frac{\mathrm{C}}{\mathrm{M}}=\mathrm{f}(\stackrel{+}{\mathrm{Y}},-\stackrel{+}{\mathrm{r}}, \boldsymbol{\pi},+\underset{\mathrm{T}}{\mathrm{T}}, \overline{\mathrm{e}})
$$

where $C$ is the amount of coins and noies in circulation, $r$ is entcrest rates, $\pi$ is inflation, $T$ is tax burden and $\mathrm{e}$ is exchange rates. The excess holdings of currency due to taxation will be the main indicator of the black economy. The effect of the tax burden on currency holdings can be estimated once the function of demand for currency is estimated econometrically.

To do so, assume that $\alpha_{0}$ is the estimated parameter of fax variable, then we can write the proxy equation for the excess demand for currency in the black economy as: 
$C_{B}=\alpha_{0}\left(T-T_{0}\right)$

where $C_{B}$ is the amount of excess demand for currency in the black economy due to taxation, $T_{0}$ is the tax burden of a particular yea: which is assumed that the black economy does not exist.

$Y_{B}=C_{B} \cdot V_{B}$

Moreover, we can also estimate the amount of the tax evasion $\left(T_{E}\right)$ as follows:

$T_{E}=Y_{B} \cdot T$

However it is clear that the size of the black economy relative to the formal economy will be equal to the amount of the tax evasion relative to the total tax revenues. Therefore, estimating the amrount of tax evasion will not produce more evidence on the size of the black economy apart from extra information on the loss of the tax revenues during the estimation period. Thus, this study does not provide this extra information because of the above-mentioncd reason.

\section{EVALUATION DF THE RESULTS}

The demand for currency holding was computcd for the Turkish case and the brief summary of the computer basid results and data definitions with their sources are included in Appendix 1.

The estimated size of the black economy relative to the formal size of economy for the estimation period is presented in Table 1 .

As Table 1 presents the that there was not black economic activity existing due to taxation. Morcover, the estimated size of the black exonomy is quite consistent with the previous studies in the sams context. However, it is smaller than general perceptions. Nonetheless, the size of the black cconomy appears ti) be increasing from the beginning of 1970 and has become more significant in the 1990s:

Table 1: The Estirnated Size of the Bliack Economy in Turkey $\%$ of Published GNP

\begin{tabular}{|l|l|l|l|l|l|}
\hline 1969 & 0.00 & 1979 & 2.46 & 1989 & 3.77 \\
\hline 1970 & 1.76 & 1980 & 2.8 & 1990 & 4.47 \\
\hline 1971 & 1.94 & 1981 & 3.30 & 1991 & 5.23 \\
\hline 1972 & 1.91 & 1982 & 2.6 & 1992 & 6.95 \\
\hline 1973 & 2.00 & 1983 & 2.69 & 1993 & 8.15 \\
\hline 1974 & 1.98 & 1984 & 2.8 & 1994 & 9.49 \\
\hline 1975 & 2.18 & 1985 & 3.8 & 1995 & 10.07 \\
\hline 1976 & 2.28 & 1986 & 3.84 & 1996 & 9.60 \\
\hline 1977 & 2.17 & 1987 & -3.88 & 1997 & 9.28 \\
\hline 1978 & 2.34 & 1988 & 4.12 & & \\
\hline
\end{tabular}


Indeed, the 1990s have attracted a great deal of interest in the black economic activities in Turkey. As a result, several studies have been conducted to determine the size of the black economy. Even though this study puts a great deal of emphasis on the tax variable (i.e. tax burden), it did not fluctuate much during the estimation period and can be considered relatively small ranging from $11 \%$ to $19 \%$ of GNP. However, the size of the black economy has increased significantly in the 1980 s which implies that there are some other factors behind the black economy activities in addition to tax burden.

Nevertheless, the result presented here requires very cautions evaluations since there are a number of limitations being applied in the process of the estimation. For example, it was assumed that currency is the main medium of exchange in the black economy. This assumption is particularly questionable as a vast financial liberalization and innovation took place in the late 1980s and the 1990s. As a result, individuals have all kind of new financial instruments and use them locally and internationally freely. Despite the fact that the scope of this study does not cover the development of altemative payment instruments such as credit and debit cards, money coupons, and foreign currencies, it appears that the alternative payment instrument substitutes domestic currencies to some extent. Moreover, assuming that the velocity of money is the same in the black economy and in the formal economy, this is not consistent with the nature of the black economic activities. As one may e0xpect, either there may be a larger velocity of money in the black economy due to fear of prosecution or there may be a smaller vecolity of money due to the other alternative payments. However, these effects could not mbe included in this study either. Finally, assuming that the base year did not have any black economic activity may seem to be quite puzzling. Nevertheless, with the help of this assumpiton we are able to estimate the lower bounds of the black economy. Thus, the unestimated size of the black economy will be cither equal to or greated than the estimations.

\section{CONCLUSION}

This study provides some more fresh evidence on the size of the black economy in Turkey. The modelh adopted here is an econometric application of demand for currency which is extensively used to determine the size of black economic activities. The estimations presented are very model based and therefore results should be evaluated with certain limtations. The main conclusion of this study is that the size of the black economy has become very noticeable in the 1990s. However, despite general perceptions, the size of the black economy estimated is relatively small and is driven mainly by the tax burden.

In the light of the concurrent tax reforms' that the Turkish government has been trying to implement, we may conclude to some extent that an increase in the tax burden may cause an increase in the size of the black economy.

As far as this study is concerned, the lower bounds of the black economy is as high as $10 \%$ of the official economy which was roughly 18 billion US dollars as of 1970.

Considering the adverse effects on the use of economic resources and causing bias in conducting macroeconomic policies, the effects of the black economy will be much 
more distruptive such as in the case of a developing country, Turkey. Therefore, the authorities should seek to eliminate the causes of the black economic activities rather than implementing policies such as increasing taxes which may aggravate the current situation.

\section{APPENDIX 1}

The following demand for currency equation was estimated econometrically for the Turkish case. Ordinary Least Squares (OLS) method was used on the econometric package programme of micro TSP version 7.0.

The summarized form of the computer print out of the equation is as below:

$$
\begin{aligned}
& \log \left(C / M_{2}\right)=-2.694+0.331 \log (\mathrm{GNP})+0.026 . \mathrm{TAXR}+0.003 \text { TEFE-0.0477 } \log (\mathrm{DOL} T L) \\
& \begin{array}{llll}
(-6.783)(2.800) & (2.208) & (3.353) \quad(-3.543)
\end{array} \\
& R^{2}=0.903 \quad R^{-2}=0.873 \quad \text { DW }=1.93 \quad \text { SER }=0.08 \quad F=29.70
\end{aligned}
$$

The equation was estirnated on annual data covering the period 1969 to 1997. Standard statistical tests were applied for the adequacy of the estimated equation and it passed all the tests at the five percent level. $t$ values are in parenthesess. The interest rate variable ( $r$ ) was left out of the equation after the several computer based experiments as this variable did not seem to contribute to the changes in the dependent variable.

On estimating the amount of the income generated by the black economy, the velocity of liquid money supply (i.e. $V_{1}=G N P / M_{1}$ ) was used. But the $C / M_{2}$ ratio was used to calculate the ratio of the excess currency holdings. As put forward by Tanzi (1986), the $C / M_{2}$ is a better ratio than the $C / M_{1}$ and it is consistent to use $V_{1}$ to determine the income behind a given "underground" use of currency (Tanzi, 1986:805).

\section{Data Definitions And Sources}

GNP : Gross National Product, at current producer's prices. Source: SIS.

C : The amount of money in circulation. Source : CBT.

M1 : Money stuck $=\mathrm{C}+$ demand deposits. Source $:$ CBT.

M2 : Money stock $=$ M1 + time deposits. Source : CBT.

DOLTL : US dollar - Turkish Lira cxchange rates. Buying and selling rates mid-year averages. Source : CBT.

TAXR : The total amount of direct and indirect taxes to the GNP. (i.e. Tax burden Source: SIS. 


\section{REFERENCES}

Aluğ, O. (1994), Kayıtdısı Ekonomi, Cem Ofset, Istanbul.

Bhattacharyya, D. K. (1990), "An Econometric Method of Estimating the Hidden Economy, United Kingdom (1964-1984): Estimates and Tests", The Economic Journal, 100, 703-717.

Cagan, P. (1958), "Demand for Currency to the Total Money Supply", Journal of Political Economy, 66, 303-328.

Derdiyok, T. (1993), "Türkiye'nin Kayıtdışı Ekonomisinin Tahmini", Türkiye Iktisat Dergisi, 14, 54-63.

Dura, C. (1997), "Kayıtdışı Ekonomi Kavramı, Sebep ve Etkiler, Ölçülmesi, Mücadele Yollan ve Türk Ekonomisindeki Yeri", Mülkiye Dergisi, Ocak/Nisan, 3-12.

Fagan, P. G. (1997), "The Black Economy in Ireland", Irish Banking Review, Summer, 19-25.

Feige, E. L. (1986), "A Re-examination of Underground Economy in the United States: A Comment on Tanzi", IMF Staff Papers, 33(4), 768-781.

Frey, S.B. Weck, H. And Pommerhene, W.W. (1982), "Has the Shadow Economy Grown in Germany? An Explanatory Study", Weltwirtschaftliches Archiv. $118,499-524$.

Frey, S. B. and Weck, H. (1983), "What Produces a Hidden Economy? An International Cross Section Analysis", Southern Economic Journal, 49, 822-832.

Frey, S.B. and Weck, H. (1983), "Estimating the Shadow Economy: A 'Naive' Approach", Oxford Economic Papers, 41, 23-44.

Gutmann, P.M. (1977), "The Subterranean Economy", Financial Analysts" Journal, 33, 26-28.

Kasnakoğlu, Z. (1993), "Monetary Approach to the Measurement of Unrecorded Economy in Turkey", METU Studies in Development 20, 87-111.

Korbanski, A. (1981), "The Second Economy in Poland", Journal of International Affairs, 35, 1-12.

Mathews, K.G.P. (1982), "Demand for Currency and the Black Economy in the UK", Journal of Economic Studies, 9, 3-22.

Özsoylu, A.F. (1993), "Gizli Ekonomi: Tanım, Sebepleri, Türkiye'deki Boyutlarn", Iktisat Dergisi, Şubat/Marh, 35-58.

State Institute Of Statistics (SIS), Statistical Yerabooks of Turkey, Various Issues. 
Smith, S. (1986), Britain's Shadow Economy, Clarendon Press, Oxford.

Şengül, S. (1997), Kayıldısı Ekonomi, Imaj, Ankara.

Tanzi, V. (1980), "The Underground Economy in the United States: Estimates and Implications", Bcinca Nazionale Del lavaro Quarterly Review, 33, 427-453.

Temel. A., Şimşck, A., and Yazıcı, K. (1994), "Kayıtdışı Ekonomi Tanimı, Tespit Yöntemleri ve Türk Ekonomisindeki Büyüklügüu", /şletme ve Finans, 104, 1033.

The Central Bank of The Republic of Turkey (CBT), Quarterly Bulletins, various issues. 